\title{
Pelatihan Pengajaran Pembagian Bilangan Pecahan Bagi Guru Sekolah Dasar di Provinsi Jambi
}

\author{
Mahyudin', MildeWahyu, Sugilar \\ UPBJJ- UT Jambi ${ }^{1}$
}

\begin{abstract}
Abstrak
Penelitian Abdimas ini berjudul "Pelatihan Pengajaran Pembagian Bilangan Pecahan Bagi Guru Sekolah Dasar Negeri di Propinsi Jambi" di SD Negeri 21/IV.Jl KH A.Somad Rt 4 Kelurahan Mudung Laut Kecamatan Pelayangan Kota Jambi Kode Pos 36252. Tujuan Abdimas ini adalah untuk ; (1) Miningkatkan kemampuan kecakapan hidup- life skill kepada guru - guru SD Negeri rayon KKG Kecamatan Pelayangan yang berpusat di SD Negeri 21/IV.Jl KH A.Somad Rt 4 Kelurahan Mudung Laut Kecamatan Pelayangan Kota Jambi Kode Pos 36252. (2) Memberi pemahaman kepada masyarakat mitra tetang Pengajaran Pembagian Bilangan Pecahan dan manfaat yang dihasilkan. (3) Menggugah jiwa pendidik yang professional dengan membentuk Kelompok Kerja Guru (KKG). Abdi kepada Masyarakat ini merupakan model pendekatan Analisis Kebutuhan dan Intervensi sesuai dengan tujuan dan sasaran yaitu; Perizinan, Perekrutan, Sosialisasi program, Pelaksanaan Pelatihan. Secara simultan Pelatihan Pengajaran Pembagian Bilangan Pecahan Bagi Guru Sekolah Dasar Negeri di Propinsi Jambi ini dapat meningkatkan kemampuan kecakap hidup/ life skill terutama guru-guru SD Negeri kelompok KKG, masyarakat mitra SD Negeri 21/IV.Jl KH A.Somad Rt 4 Kelurahan Mudung Laut Kecamatan Pelayangan Kota Jambi Kode Pos 36252 .
\end{abstract}

Kata kunci :Pelatihan, Pengajaran Pembagian Bilangan Pecahan.

\section{PENDAHULUAN \\ Analisis Situasi}

Faktor guru sering menjadi sorotan utama untuk menjelaskan keberhasilan siswa dalam belajar matematika. Seorang pakar matematika ketika diminta harian Kompas (Kompas, 2012) untuk menanggapi rendahnya prestasi belajar matematika menunjukkan buruknya pembelajaran matematika akibat kualitas guru matematika yang rendah. Di lain kesempatan, terkait dengan penerapan Kurikulum 2013, pakar pendidikan Suyanto (2013) mengatakan bahwa guru memegang kunci utama dalam suksesnya sebuah implementasi kurikulum, guru yang baik (410ecimal410onal) akan mampu dan sanggup mengubah kurikulum yang kurang baik sekalipun menjadi sebuah program pembelajaran yang bermakna bagi para siswa. Shadiq (2013) menyatakan bahwa peran guru matematika sangat penting dan guru matematika akan sangat menentukan keberhasilan siswanya, karena dengan kemampuannya, gurulah yang akan memerahkan atau menghijaukan siswanya.

Peranan guru dalam pembelajaran memiliki 410ecimal410 yang luas. Akhirini, beberapa peneliti pendidikan matematika memokuskan perhatian pada pengetahuan matematika untuk mengajar (PMM). PMM dianggap sebagai suatu kompetensi guru yang memungkinkan guru melaksanakan pembelajaran matematika yang berkualitas. Hal ini didasari oleh berbagai temuan penelitian seperti yang disimpulkan oleh Hill \& Ball (2005) bahwa dampak peranan guru terhadap hasil belajar siswa digerakkan oleh kemampuan guru untuk memahami dan menggunakan pengetahuan isi materi pelajaran untuk melaksanakan kegiatan mengajar. Mengutip berbagai sumber mengenai PMM untuk membelajarkan siswa dalam mata pelajaran matematika, Gencturk (2012) menyatakan bahwa "[T]eachers must know and understand deeply the mathematics they are teaching and be able to draw on that knowledge 
with flexibility in their teaching tasks" ( $\mathrm{p}$. 17).

Sugilar \& Tarhadi (2014) melakukan penelitian untuk mengidentifikasi pengetahuan matematika untuk mengajar pembagian bilangan pecahan. Penelitia ini melibatkan para pakar pendidikan matematika dari Universitas Jambi dan Universitas Terbuka. Hasil penelitian menghasilkan 16 butir kompetensi terkait dengan pengetahuan matematika untuk megajar pembagian bilangan pecahan di sekolah dasar. Tidak semua kompetensi tersebut dipelajari pada pendidikan guru sekolah dasar di Universitas Terbuka. Sugilar (2015) melaporkan bahwa hanya $50 \%$ dari kompetensi yang dibutuhkan guru untuk mengajar pembagian bilangan pecahan di sekolah dasar tercantum dalam kurikulum S-1 PGSD Universitas Terbuka. Oleh karena itu, guru-guru di Kota Jambi, yang sebagian besar merupakan lulusan Universitas Terbuka, memerlukan tambahan kompetensi pengetahuan matematika untuk mengajar pembagian bilangan pecahan di sekolah dasar.

Dalam Undang-Undang Republik Indonesia Nomor 14 Tahun 2005 tentang Guru dan Dosen pengetahuan guru yang dimaksud disebut dengan kompetensi yang memiliki pengertian lebih luas, yaitu bahwa kompetensi adalah seperangkat pengetahuan, keterampilan, dan perilaku yang harus dimiliki, dihayati, dan dikuasai oleh guru atau dosen dalam melaksanakan tugas keprofesionalan. Selanjutnya Undang-Undang tentang Guru dan Dosen tersebut menyebutkan bahwa guru perlu memiliki kompetensi yang diperlukan sesuai dengan bidang tugasnya dan kompetensi guru tersebut meliputi kompetensi 411ecimal411o, kompetensi kepribadian, kompetensi 411ecima, dan kompetensi 411ecimal411onal yang diperoleh melalui pendidikan profesi.

\section{Permasalahan Masayarakat/Mitra Permasalahan}

Berdasarkan analisis situasi di atas, diidentifikasi masalah sebagai berikut :
- Hasil belajar matematika pada sekolah dasar di Jambi masih belum menggembirakan. Hal ini sebagian disebabkan oleh pembelajaran matematika yang belum memenuhi standar kualitas. Belum baiknya pembelajaran matematika di sekolah dasar sebagian disebabkan oleh kompetensi guru yang belum sesuai dengan kebutuhan pengajaran.

- Hanya 50\% dari kompetensi pengetahuan matematika untuk mengajar pembagian bilangan pecahan tercantum dalam kurikulum pendidikan guru sekolah dasar di Universitas Terbuka.

- Kepala Sekolah Dasar Negeri 21 tersebut di atas menginginkan gurugurunya mendapat pelatihan untuk menambah wawasan pengetahuan mereka dalam mengajar, khususnya pengajaran pembagian bilangan pecahan.

Program pengabdian kepada masyarakat yang diusulkan ini adalah suatu program pelatihan bagi guru-guru sekolah mitra untuk menambah pengetahuan matematika untuk mengajar pembagian bilangan pecahan. Sekolah mitra yang terplih untuk kegiatan ini ialah Sekolah Dasar Negeri 21 sebagai tempat rayon KKG dengan anggota ( terdiri SDN 21,SDN 04,SDN 10,SDN 44, SD 71,SDN 170)sebanyak 6 SDN. Masing-masing SD mengirimkan sebanyak 8 orang guru utusan dari guru kelas 3,4,5 dan kelas 6 . Alamat Rayon KKG tersebut di Jl. KH.A. Somad , Kelurahan Mudung Laut, Kecamatan Pelayangan, Kota Jambi. Pemilihan materi pembagian bilangan pecahan didasarkan pada pentingnya pemahaman mengenai bilangan pecahan di sekolah dasar, seperti yang dinyatakan oleh Lo \& Luo (2012) bahwa (1) bilangan pecahan merupakan topik yang dipandang menantang untuk dipelajari oleh siswa dan diajarkan oleh guru, (2) penguasaan materi bilangan pecahan merupakan 
prasyarat untuk mempelajari aljabar, dan (3) pembagian bilangan pecahan melibatkan satuan pecahan yang mencakup semua konsep dan keterampilan yang terkait dengan pecahan.

\section{Kelayakan Pelaksanaan Abdimas}

Instruktur pada kegiatan pelatihan ini merupakan dosen Program Studi Pendidikan Matematika pada FKIP-UT yang telah melakukan berbagai penelitian mengenai pengajaran matematika, dosen strategi pembelajaran dan dosen manjemen pembelajaran . Kegiatan abdimas ini merupakan diseminasi hasil penelitiannya untuk dapat 412merima manfaat kepada masyarakat. Sedangkan, anggota kegiatan abdimas ini merupakan tenaga-tenaga ahli yang telah banyak melakukan kegiatan abdimas dan berpengalaman dalam penyelenggaraan pelatihan.

Sinegitas dalam tim terjamin karena baik ketua maupun anggota kegiatan abdimas ini merupakan pegawai /Dosen UPBJJ-UT Jambi. Di samping itu, hubungan dengan mitra sangat baik karena semua personal mitra tersebut merupakan alumni UT.

Agar tercapai peningkatan pengajaran pembagian bilangan pecahan bagi guru Sekolah Dasar Negeri masyarakat mitra kelompok KKG Kecamatan Pelayangan Jambi sesuai dengan harapan , hendaknya setiap komponen yang terlibat dan berperan harus saling terkait satu sama lainnya dan saling membantu untuk meningkatkan pengajaran yang berkualitas bagi guru Sekolah Dasar Negeri

\section{Strategi dan Solusi \\ Strategi dan Solusi yang Ditawarkan}

Tujuan umum dari program pengabdian kepada masyarakat ini adalah memberikan pengetahuan matematika lanjut yang berdasarkan hasil penelitian terdahulu yang dilakukan oleh Sugilar \& Tarhadi (2014) merupakan pengetahuan matematika untuk mengajar pembagian bilangan pecahan di sekolah dasar.

Guru yang telah mengikuti pelatihan ini diharapkan akan mengajar pembagian bilangan pecahan di sekolah dasar secara lebih baik karena memiliki bekal profesional dalam isi pengajaran yang lebih dalam dan luas. Selain itu, kegiatan pelatihan ini diharapkan dapat mendekatkan UT kepada masyarakat dan dirasakan sebagai lembaga pendidikan yang bermanfaat bagi masyarakat, khsusunya Kota Jambi.

Pelatihan dilaksanakan dalam kurun dua bulan. Kegiatan pelatihan dilaksanakan dalam delapan kali pertemuan, masingmasing 2 jam setiap pertemuannya. Rincian kegiatan dalam tiap pertemuan disajikan dalam Tabel 1 berikut:

Tabel 1.

Materi dan Strategi Pelatihan

\begin{tabular}{|c|c|c|}
\hline $\begin{array}{c}\text { Pertemuan } \\
\mathrm{Ke}\end{array}$ & Materi & Strategi \\
\hline 1 & $\begin{array}{l}\text { - Perkenalan dan penyampaian rencana } \\
\text { kegiatan pelatihan } \\
\text { - Materi pembagian bilangan sekolah } \\
\text { dasar di sekolah: } \\
\checkmark \text { Memahami berbagai bentuk } \\
\text { pecahan (pecahan biasa, campuran, } \\
\text { desimal dan persen) dan dapat } \\
\text { mengubah bilangan pecahan } \\
\text { menjadi bilangan desimal, serta } \\
\text { melakukan perkalian dan pembagian }\end{array}$ & $\begin{array}{l}\text { - } \text { Diskusi } \\
\text { - Pemutaran Video tentang } \\
\text { pembagian bilangan } \\
\text { pecahan }\end{array}$ \\
\hline 2. & Memahami operasi hitung yang & - Presentasi \\
\hline
\end{tabular}




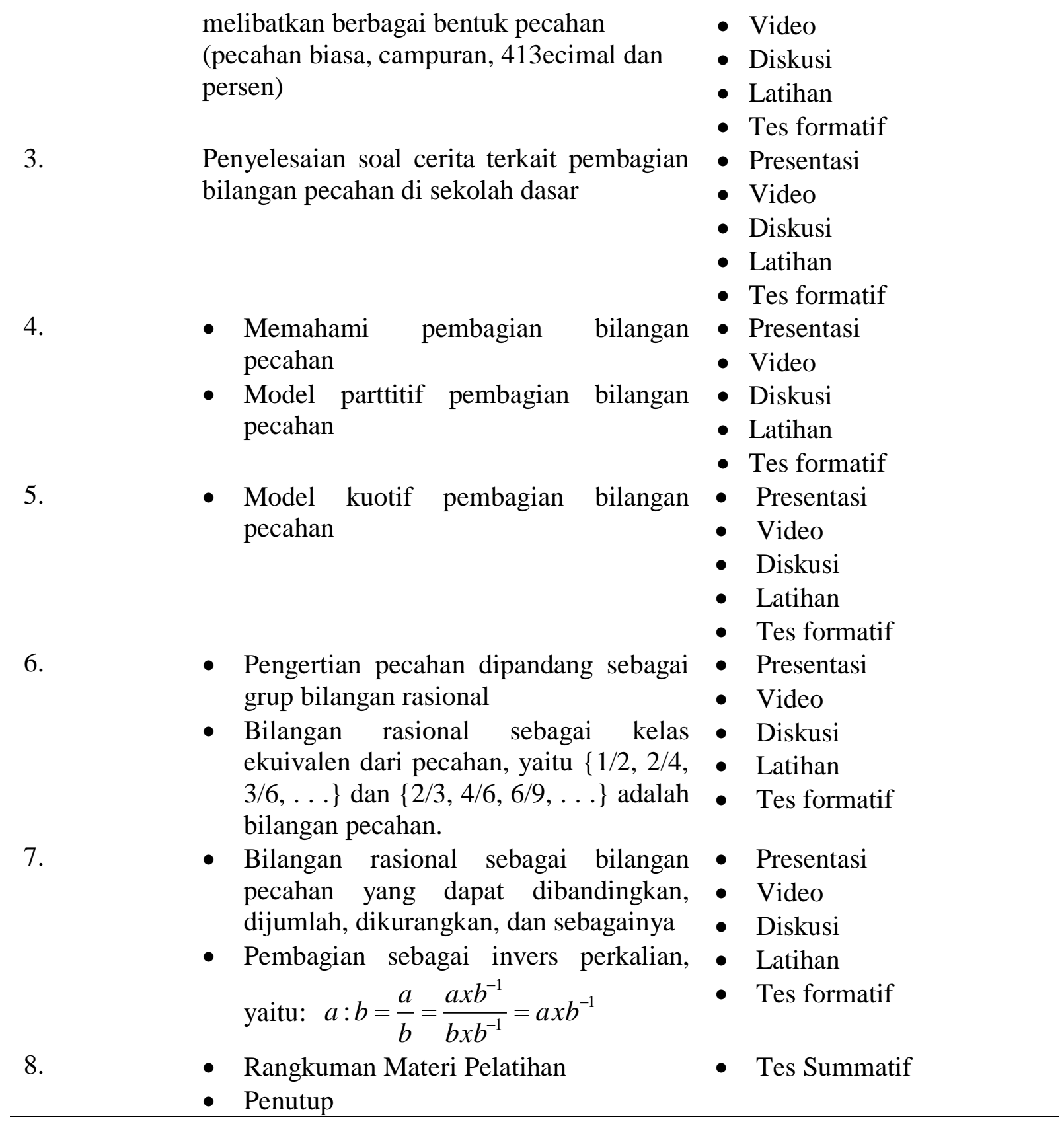

\section{Target Luaran}

Target luaran kegiatan abdimas ini ialah terlatihnya 48(empat puluh delapn), terdiri dari guru-guru di Sekolah Dasar Negeri 21 sebagai tempat rayon KKG dengan anggota ( terdiri SDN 21,SDN 04,SDN 10,SDN 44, SD 71,SDN 170)sebanyak 6 SDN. Masing-masing SD mengirimkan sebanyak 8 orang guru utusan dari guru kelas 3,4,5 dan kelas 6 . Alamat Rayon KKG tersebut di Jl. KH.A. Somad , Kelurahan Mudung Laut, Kecamatan Pelayangan, Kota Jambi. Guru yang mengikuti pelatihan ini merupakan guru-guru lulusan UT yang berada di Kota Jambi. Guru yang telah mengikuti pelatihan ini diharapkan akan mengajar pembagian bilangan pecahan di sekolah dasar secara lebih baik karena memiliki bekal profesional dalam isi pengajaran yang lebih dalam dan luas. Selain itu, kegiatan pelatihan ini diharapkan dapat mendekatkan UT kepada masyarakat dan dirasakan sebagai lembaga pendidikan yang bermanfaat bagi masyarakat, khsusnya masyarakat Kota Jambi. 
Jadwal Kegiatan

\begin{tabular}{llcccccc}
\hline No & Agenda Kegiatan & Juli & Agustus & September & Oktober & November & Desember 2017 \\
\hline 1 & Perizinan/Persiapan & $\mathrm{X}$ & & & & & \\
& Abdimas & & & & & & \\
2 & Perekrutan peserta & $\mathrm{X}$ & & & & & \\
3 & Sosialisasi program & $\mathrm{X}$ & & & & \\
4 & Penyajian materi & & $\mathrm{XXX}$ & $\mathrm{XXXX}$ & & & \\
5 & Laporan Tahap I & & & & $\mathrm{X}$ & $\mathrm{X}$ & $\mathrm{XX}$ \\
6 & Evaluasi & & & & \\
7 & Tahab finalisasi dan & & & & & & \\
& pembuatan laporan & & & & & & \\
\hline
\end{tabular}

\section{HASIL DAN PEMBAHASAN}

Hasil dari Pelatihan Pengajaran

Pembagian Bilangan Pecahan Bagi Guru Sekolah Dasar di SD 21/IV Jl.KH.

A.Somad Kelurahan Mudung Laut,

Kecamatan Pelayangan, Kota Jambi antara

lain:
1. Peserta Pelatihan terdiri Guru-guru SDN 21,SDN 04,SDN 10,SDN 44, SD 71, dan SDN 170 sebanyak 48 orang guru, dari guru kelas 1 sampai guru kelas 6.

2. Materi yang disajikan adalah :

Materi / Ipteks yang Ditransfer

- Pembagian bilangan sekolah dasar di sekolah.

- Berbagai bentuk pecahan (pecahan biasa, campuran, desimal dan persen), perubahan bentuk bilangan pecahan menjadi bilangan desimal, dan perkalian serta pembagian bilangan pecahan

2. - Operasi hitung yang melibatkan berbagai bentuk pecahan (pecahan biasa, campuran, desimal dan persen)

3. - Soal cerita terkait pembagian bilangan pecahan di sekolah dasar

4. - Konsep pembagian bilangan pecahan

- Model parttitif pembagian bilangan pecahan

5. - Model kuotif pembagian bilangan pecahan

6. - Pengertian pecahan dipandang sebagai lapangan (field) bilangan rasional

- Bilangan rasional sebagai kelas ekuivalen dari pecahan, yaitu $\{1 / 2,2 / 4$, $3 / 6, \ldots\}$ dan $\{2 / 3,4 / 6,6 / 9, \ldots\}$ adalah bilangan pecahan.

7. Bilangan rasional sebagai bilangan pecahan yang dapat dibandingkan, dijumlah, dikurangkan, dan sebagainya

- Pembagian sebagai invers perkalian, yaitu: $a: b=\frac{a}{b}=\frac{a x b^{-1}}{b x b^{-1}}=a x b^{-1}$

Peserta pelatihan terlihat tertarik dengan materi yang disajikan dengan serius tetapi santai.

3. Pelatihan berlangsung dengan lancar dimana pada tahab awal adalah memotivasi para guru untuk mau berlatih Pengajaran Pembagian Bilangan Pecahan sesuai dengan materi ada dalam tabel. Supaya pelaksanaan pelatihan tidak kaku dan tegang maka penyaji materi dibarengi dengan Tanya jawab,diskusi, dan pemutaran video.

4. Pada saat pelatihan peserta begitu antusias mengikuti pelatihan karena sesi Tanya jawab panitia menyediakan door prize bagi peserta yang menjawab dengan benar.

Berdasarkan pengamatan pada saat pelatihan tidak ditemukan kendalan yang signifikan, namun diharpkan adanya proses berkelanjutan untuk pelatihan pengajaran 
pembagian bilangan pecahan bagi guruguru SD.

\section{SIMPULAN}

1. Sebelum melakukan inovasi pengajaran pembagian bilangan pecahan bagi masyarakat mitra atau rombel KKG, yang beralamat di Jl. KH. A. Somad, Kelurahana Mudung Laut, Kecamatan Pelayangan , Kota Jambi sangat diperlukan adanya sosialisasi dan deplot aga para guru lebih siap dalam melakukan adopsi invasi.

2. Dalam penyebaran suatu inovasi pengajaran sngat perlu melibatkan peran serta pembimbing dan masyarakat mitra

3. Kerja sama yang antara semua pihak terkait yaitu , Tim pengabdian kepada masyarakat UPBJJ-UT Jambi, kelompok masyarakat mitra rombel KKG guru SD N Kecamatan Pelayangan , Kota Jambi.

\section{DAFTAR PUSTAKA}

Prestasi Sains dan Matematika Indonesia Menurun. (2012/12/14). Retrieved from

http://edukasi.kompas.com/read/2012 /12/14/09005434/Prestasi.Sains.dan.

Matematika.Indonesia.Menurun

Suyanto. (2013). "Guru dalam pembelajaran". Kompas, 1/04/2013. Retrieved

from:http://regional.kompas.com/rea d/2013/04/01/02225375/twitter.com

Shadiq, F. (2013). "Peran penting guru matematika dalam mencerdaskan siswanya", APRIL 28, 2013 in ARTIKEL, PENDIDIKAN. Retrieved from: http://p4tkmatematika.org/2013/04/p eran-penting-guru-matematikadalam-mencerdaskan-siswanya/

Hill, H.C., Schilling, S.G., \& Ball, D.L. (2005). Developing measures of teachers'mathematics knowledge for teaching. Elementary School Journal 105, 11-30.

Gencturk, Y.C. (2012). Teachers' mathematical knowledge for teaching, instructional practices, and student outcomes. Dissertation, Submitted in partial fulfillment of the requirements for the degree of Doctor of Philosophy in Secondary and Continuing Education in the Graduate College of the University of Illinois at Urbana-Champaign. Retrieved from: https://www.ideals.illinois.edu/bitstre am/handle/2142/31173/CopurGenctu rk Yasemin.pdf?sequence $=1$

Sugilar \& Tarhadi. (2014). Identifikasi pengetahuan matematika untuk mengajar pembagian bilangan pecahan di sekolah dasar. Prosiding Seminar Nasional Matematika Pendidikan Matematika,Universitas Santha Dharma, Yogyarta. Hlm. 543-553.

Sugilar. (2015).Analisis isi kandungan pengetahuan matematika untuk mengajar pembagian bilangan pecahan dalam bahan ajar program pendidikan S-1 guru SD di Universitas Terbuka. Makalah yang dipresentasikan pada Seminar Nasional Matematika dan Pendidikan Matematika STKIP PGRI Sumatera Barat 2105.

Lo, J., J. \& Luo, F. (2012). "Prospective Elementeray Teachers' Knowledge of Fraction Division". J. Math Teacher Educ, 15:481-500. 